\title{
Naturally Inspired Molecules as Multifunctional Agents for Alzheimer's Disease Treatment
}

\author{
Angela Rampa ${ }^{1, *}$, Andrea Tarozzi $^{2}$, Francesca Mancini ${ }^{1}$, Letizia Pruccoli ${ }^{2}$, \\ Rita Maria Concetta Di Martino ${ }^{1}$, Silvia Gobbi ${ }^{1}$, Alessandra Bisi ${ }^{1}$, Angela De Simone ${ }^{2}$, \\ Francesco Palomba ${ }^{3}$, Nelsi Zaccheroni ${ }^{3}$ and Federica Belluti ${ }^{1, *}$ \\ 1 Department of Pharmacy and Biotechnology, Alma Mater Studiorum-University of Bologna, \\ Via Belmeloro 6, 40126 Bologna, Italy; francymancini@gmail.com (F.M.); \\ ritamaria.dimartino2@unibo.it (R.M.C.D.M.); silvia.gobbi@unibo.it (S.G.); alessandra.bisi@unibo.it (A.B.) \\ 2 Department for Life Quality Studies, Alma Mater Studiorum-University of Bologna, Corso D'Augusto 237, \\ 47921 Rimini, Italy; andrea.tarozzi@unibo.it (A.T.); letizia.pruccoli@studio.unibo.it (L.P.); \\ angela.desimone2@unibo.it (A.D.S.) \\ 3 Department of Chemistry “G. Ciamician”, Alma Mater Studiorum-University of Bologna, Via Selmi 2, \\ 40126 Bologna, Italy; francesco.palomba3@unibo.it (F.P.); nelsi.zaccheroni@unibo.it (N.Z.) \\ * Correspondence: angela.rampa@unibo.it (A.R.); federica.belluti@unibo.it (F.B.) ; \\ Tel.: +39-051-2099710 (A.R.); +39-051-2099732 (F.B.)
}

Academic Editors: Michael Decker, Diego Muñoz-Torrero and Derek J. McPhee Received: 23 March 2016; Accepted: 11 May 2016; Published: 16 May 2016

\begin{abstract}
Alzheimer's disease (AD) has been defined as a multi-factorial disorder resulting from a complex array of networked cellular and molecular mechanisms. In particular, elevated levels of $\mathrm{A} \beta$ protein and its aggregation products in the presence of metal ions proved to be highly neurotoxic and therapeutic strategies aimed at preventing $A \beta$ generation and oxidative stress may represent an effective approach for $\mathrm{AD}$ treatment. A recent paradigm for the treatment of complex diseases such as AD suggests the employment of multifunctional compounds, single chemical entities capable of simultaneously modulating different targets involved in the pathology. In this paper, the "pharmacophores combination" strategy was applied, connecting the main scaffold of the BACE-1 ligand 1 to that of the chalcone 2 , as metal chelating pharmacophore, to obtain a small library of compounds. Conjugate 5 emerged as the most interesting derivative, proving to inhibit BACE-1 with low-micromolar potency, and showing neuroprotective effects. In particular, 5 proved to be able to protect from metal-associated oxidative stress by hampering intracellular $\mathrm{Cu}^{2+}$-induced ROS formation without any direct neurotoxic effect.
\end{abstract}

Keywords: AD; BACE-1; benzophenone; chalcone; metal chelation; natural products; Reactive oxygen species

\section{Introduction}

Alzheimer's disease (AD), characterized by a progressive decline of cognitive and behavioral functions, represents a considerable social, economic, and health burden due to its ever-increasing incidence and prevalence. This is currently estimated to affect 24 million patients and this number is predicted to increase fourfold by the year 2050 [1]. AD has been defined as a multi-factorial disorder, being the result of a complex array of networked cellular and molecular mechanisms contributing to neuronal dysfunction and degeneration. A recent paradigm to treat complex diseases, widely accepted by the medicinal chemistry community, suggests the use of multifunctional compounds (MFCs), also called multitarget drugs, which are single chemical entities capable of simultaneously modulating different targets or pathways involved in the pathology $[2,3]$. 
A number of key pathological changes can be observed in AD brain, namely amyloid- $\beta$ (A $\beta$ ) peptide extracellular deposits (amyloid neuritic plaques) and intracellular hyperphosphorylated tau protein-based microtubule assemblies (neurofibrillary tangles). Additional features include membrane-associated oxidative stress, neuroinflammation, biometal dyshomeostasis, mitochondrial dysfunction and extensive loss of neurons and synapses. To date, the exact mechanisms leading to these alterations still have to be fully uncovered.

A large body of evidence suggests that elevated levels of $A \beta$ protein and its aggregation products, such as pre-fibrillary small soluble $\mathrm{A} \beta$ oligomers and dimers, are highly toxic species. They positively correlate with disease severity [4] due to their ability to trigger a cascade of neurobiological events, namely oxidative damage, neuroinflammation and neurotoxicity, ultimately culminating in brain atrophy, synaptic dysfunction and neuronal cell death [5]. Consequently, therapeutic strategies aimed at preventing $A \beta$ generation and toxicity may represent an effective approach for AD treatment. $\mathrm{A} \beta$ protein is the results of amyloid precursor protein (APP) sequential cleavage by $\beta$ - and $\gamma$-secretases. In particular, $\beta$-secretase (also known as $\beta$-site APP cleaving enzyme-1, or BACE-1), the aspartyl protease involved in the catalysis of the initial and rate-limiting step of APP processing, has been validated to play a key role in regulating the formation of $A \beta$ and related post-translational products. Clinical trials outcomes demonstrated a direct correlation between BACE- 1 inhibition and A $\beta$ reduction. Moreover, the elevated BACE-1 protein expression detected in AD patients brains [6] elected this enzyme as attractive molecular target for disease-modifying drug discovery programs focused on the development of "anti-amyloid" therapeutics. Substantial efforts have been put into the discovery of small molecules as BACE-1 inhibitors in both academia and industry [7]. The various X-ray crystal structures of BACE-1 alone and in complex with an inhibitor represent an essential source of structural information for structure-based development of non-peptidic BACE-1 inhibitors with different core templates [7-9].

Several metal ions, among which $\mathrm{Cu}(\mathrm{II}), \mathrm{Fe}(\mathrm{II})$ and $\mathrm{Zn}(\mathrm{II})$, largely found in AD plaques, are known to be responsible for oxidative stress and neuronal cell death by promoting $A \beta$ assembly and enhancing reactive oxygen species (ROS) production [10]. Chemical entities endowed with metal chelation properties proved to be able to hamper ROS generation and toxicity, together with metal-A $\beta$ interaction, and could represent a valuable approach for reducing neurotoxicity [11].

Natural products (NPs), small molecules synthesized by the plant kingdom, can be defined "privileged structures" as they have undergone the natural selection process that allowed them to achieve structural (chemical) features for optimal interactions with a wide range of biological targets. Consequently, NPs possess different biological activities, responsible for a combination of therapeutic effects. During the last decades, NPs represented an excellent source of lead compounds [12] and this encouraged their employment as biologically pre-validated starting points for NPs-based approaches of drug design and discovery [13]. In this context flavonoids, a class of polyphenolic NPs, showed a wide therapeutic potential due to their ability to treat several human diseases including cancer, inflammation and AD. They can be regarded as multitarget compounds, since various molecular mechanisms are responsible for a single pharmacological effect. NPs proved to exert neuroprotective activity by affecting different AD networked pathways and acting through different mechanisms of actions, including suppression of neuroinflammatory responses and protection from neurotoxic injuries, such as those derived from $A \beta$ species, metal ions and oxidative stress [14]. Their metal chelation ability was shown to depend on the presence of well-defined chelation sites in their structures, such as a carbonyl function adjacent to a hydroxy group. The flavonoid-based metal chelates showed an enhancement of several beneficial biological activities, among which the antioxidant effects, compared to the corresponding simple flavonoids [15].

\section{Design Strategy}

The benzophenone core is known to be a privileged structure, suitable to be exploited to provide effective ligands for different molecular targets involved in AD [16,17]. In an effort aimed at 
obtaining multipotent AD therapeutics, our in-house collection of naturally inspired small molecules was screened against the BACE-1 enzyme, and some promising hit compounds were identified. Among them, compounds 1 and 2 (Figure 1), bearing a benzophenone and a chalcone framework, respectively, showed a promising BACE-1 inhibition (36\% and 20\%, respectively) when tested at $5 \mu \mathrm{M}$ concentration. In a previous work, the benzophenone 1, bearing a $N, N^{\prime}$-benzylmethylamine moiety, was selected as the main scaffold to be optimized, allowing us to obtain a mutitarget AD-drug candidate able to efficiently inhibit BACE-1 enzyme (low-micromolar potency) and to offer protection against $\mathrm{A} \beta$-induced neurotoxicity as well [18]. Moreover, computational studies showed that the $N, N^{\prime}$-benzylmethylamine function of $\mathbf{1}$ could appropriately interact with the catalytic dyad of the enzyme. As for the second selected scaffold, chalcones (1,3-diarylpropen-1-ones) occupy a special place as privileged structures among NPs. Peculiar chemical features of the hit 2 were an alkoxy side chain and a hydroxyl group ortho to the carbonyl function (A-ring), while the B-ring was decorated with a 3,4,5-trimethoxy substitution pattern.

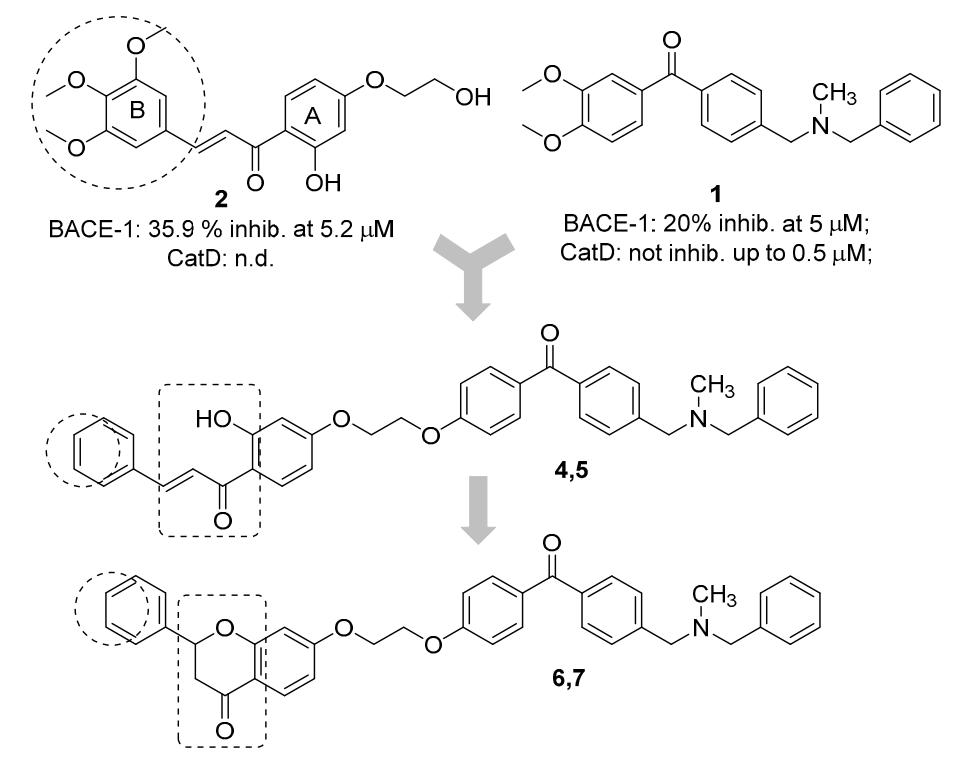

Figure 1. Design strategy for the optimization of the naturally inspired hits (1 and $\mathbf{2})$ to obtain conjugates (4-7) as BACE-1 inhibitors. Inhibitory activities of $\mathbf{1}$ and $\mathbf{2}$ are reported.

A predominant approach for the design of multitarget agents is the "pharmacophores combination" strategy, that involves the arrangement of different pharmacophore units from selected bioactive ligands to obtain analogues with an improved and expanded biological profile [19]. Accordingly, in this work, the main scaffold of the benzophenone $\mathbf{1}$ was combined with that of the chalcone 2 , which could also be considered a metal chelating pharmacophore that could allow to widen the spectrum of biological activities of the obtained conjugate (analogue 4). To preliminarily explore the SAR of this new hybrid, some structural modifications were performed, involving the replacement of the electron rich 3,4,5-trimethoxy-phenyl ring with a rigid and planar naphthalene moiety (5), since these groups proved to be valuable functions in the study of the chemical space of some AD targets such as the acetylcholinesterase enzyme [20]. Moreover, to assess the importance of the chalcone ortho-hydroxy-trans- $\alpha, \beta$-unsaturated carbonyl framework for BACE- 1 inhibition, this function was cyclized to a flavanone nucleus (to obtain compounds 6 and 7). Finally, applying a molecular simplification approach, the acetophenone-based derivative 3 was also included in the series. The new flavonoid-based conjugates were first tested on BACE-1 enzyme to assess their inhibitory potency. Then, the metal complexation potential of some selected candidates was also studied both in vitro and in solution. Finally, the ability to offer protection against metal induced oxidative stress was also investigated. 


\section{Results}

\subsection{Chemistry}

The synthetic route followed for the preparation of the chalcone-benzophenone conjugates 3-7 is depicted in Scheme 1. The hydroxylated benzophenone 8 was synthesized according to our previously described procedure [17] and then subjected to Williamson reactions with the different flavonoid-based derivatives 10-14, using a parallel synthesis apparatus, to give the final compounds 3-7. Intermediates 10-14 were obtained according to Scheme 2, in which 2,4-dihydroxyacetophenone was alkylated with 1,2-dibromoethane in hot acetone and in the presence of $\mathrm{K}_{2} \mathrm{CO}_{3}$ to obtain key intermediate 10, that underwent a Claisen-Schmidt condensation reaction with the selected aldehydes and $\mathrm{KOH}$, to produce the chalcone-based intermediates 11,12 in good yields (70\%-90\%); their cyclization to the corresponding $( \pm$ ) flavanones 13,14 was accomplished by treatment with sodium acetate in refluxing ethanol. When 2,4-dihydroxyacetophenone was alkylated with 1-bromo-ethanol under the abovementioned conditions, compound 9 was obtained, that underwent a Claisen-Schmidt condensation with 3,4,5-trimethoxybenzaldehyde to give the final compound 2 . Finally, compound 3 was obtained by Williamson reaction between 10 and 8 .

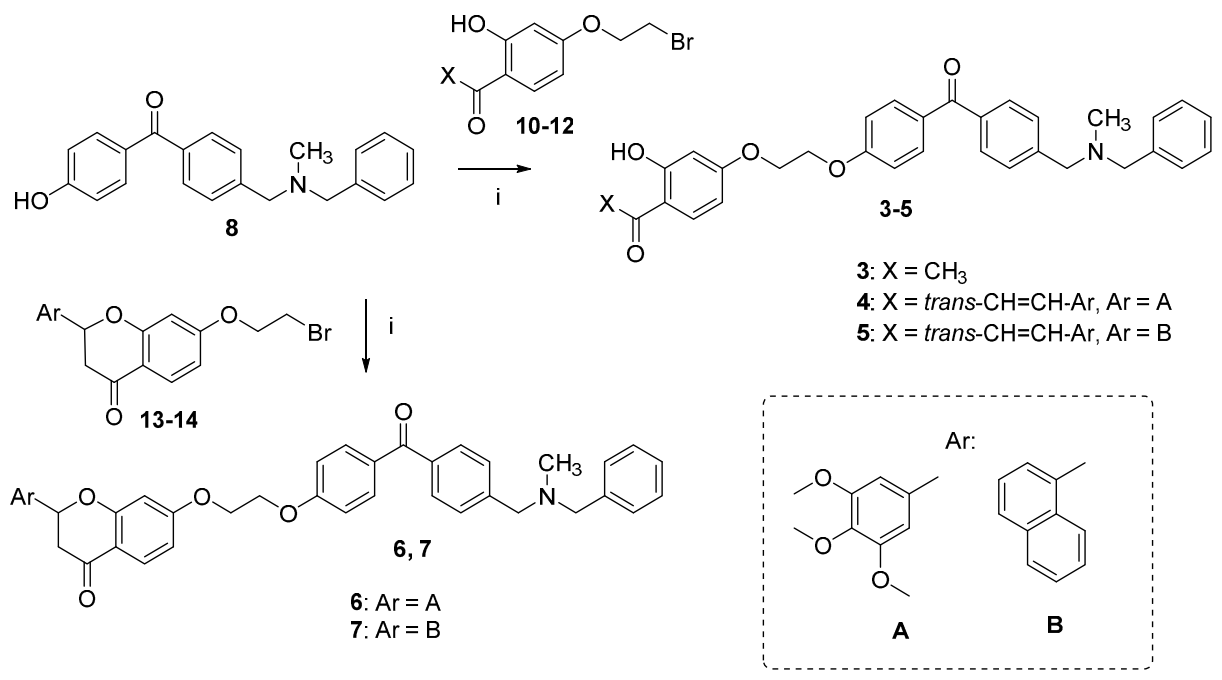

Scheme 1. Synthesis of compounds 3-7. Reagents and Conditions: (i) $\mathrm{K}_{2} \mathrm{CO}_{3}$, acetone, reflux.

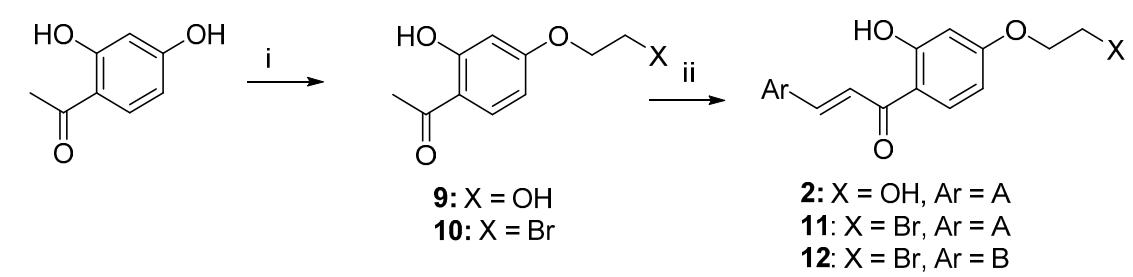<smiles>O=C1CC([Al])Oc2cc(OCCBr)ccc21</smiles>

13: $\mathrm{Ar}=\mathrm{A}$

14: $\mathrm{Ar}=\mathrm{B}$

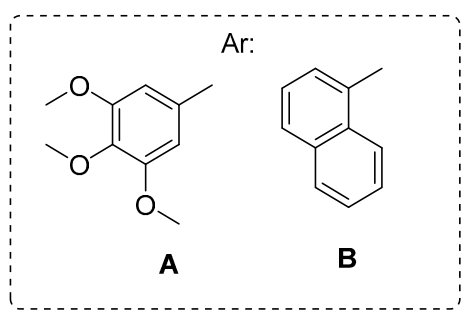

Scheme 2. Synthesis of intermediates 10-14. Reagents and Conditions: (i) 1-Bromoethanol or 1,2-dibromoethane, $\mathrm{K}_{2} \mathrm{CO}_{3}$, acetone, reflux; (ii) substituted benzaldehydes, $\mathrm{KOH}$, EtOH, rt.; (iii) $\mathrm{NaOAc}$, $\mathrm{EtOH}, 80^{\circ} \mathrm{C}$, reflux. 


\subsection{Biological Evaluation}

The new benzophenone-based hybrids 3-7 presented in this study were first evaluated for their in vitro ability to inhibit the enzymatic activity of BACE-1, by means of a biochemical assay performed using the fluorescence resonance energy transfer (FRET) methodology [21] and in comparison to inhibitor IV [22] as reference compound (Table 1 ). For the most interesting compounds 3-5, endowed with the orto-hydroxycarbonyl substitution pattern, the neuroprotective potential was determined as lack of toxic effects on neuronal cell viability and as $\mathrm{Cu}$ (II) chelating activity (Table 2); moreover, their direct interactions with $\mathrm{Cu}$ (II) ion were confirmed by a UV-vis spectrophotometric study.

Table 1. BACE-1 inhibitory potency of the new compounds 3-7 and reference compound (inhibitor IV).

Compound $h^{-1 A C E-1}$ Inhibition $\mathrm{IC}_{50}(\mu \mathrm{M})^{\mathbf{a}}$

a All data were obtained at least in triplicate, and the values listed are the average from multiple experiments, each performed in triplicate. SEM \pm standard error of the mean; ${ }^{b}$ See ref [22].

Table 2. Neurotoxicity and $\mathrm{Cu}(\mathrm{II})$ chelating activity of the studied compounds and positive control $\mathrm{Na}_{2}$ EDTA.

\begin{tabular}{ccc}
\hline Compound & ${\text { Cell Viability } \mathrm{IC}_{\mathbf{5 0}}(\boldsymbol{\mu M})^{\mathbf{a}}}^{\mathbf{C}}$ & $\mathbf{C u ( I I ) - C h e l a t i n g ~ A c t i v i t y ~ ( \% )}{ }^{\mathbf{b}}$ \\
\hline $\mathbf{3}$ & $10.89 \pm 1.63$ & $5.37 \pm 0.16$ \\
$\mathbf{4}$ & $23.66 \pm 3.54$ & $15.07 \pm 1.32$ \\
$\mathbf{5}$ & n.d & $19.73 \pm 0.30$ \\
$\mathrm{Na}_{2}$ EDTA & - & $17.10 \pm 1.44$
\end{tabular}

a Concentration of compound resulting in 50\% inhibition of cell viability after $24 \mathrm{~h}$ treatment. The values are mean \pm SD of at least two independent experiments; ${ }^{b}$ Chelating activity observed at $20 \mu \mathrm{M}$ concentration of compound and $\mathrm{Na}_{2}$ EDTA as positive control. The values are mean \pm SD of at least two independent experiments; ${ }^{\mathrm{c}}$ n.d. $=\mathrm{IC}_{50}$ not determined because less than $50 \%$ inhibition was observed at the highest concentration tested $(40 \mu \mathrm{M})$.

Finally, for the most interesting compound 5, the ability to protect from oxidative stress following complexation with $\mathrm{Cu}$ (II) was studied. 


\subsubsection{BACE-1 Inhibition}

All the newly synthesized conjugates 3-7 showed good in vitro BACE-1 inhibitory potencies, higher than the starting hits; data are reported in Table 1. More in detail, when the benzophenone scaffold was linked to the flavonoid precursor acetophenone to give compound 3, an encouraging result was obtained $\left(\mathrm{IC}_{50}=3.18 \mu \mathrm{M}\right)$. Indeed, the chalcone-benzophenone conjugates 4 and 5 also showed good BACE-1 inhibition, as their potencies were maintained in the same low-micromolar range as 3. In particular 4, bearing a 3,4,5-trimethoxyphenyl moiety, showed higher activity than the starting chalcone-based derivative 2 , and proved to be the most active of the series $\left(\mathrm{IC}_{50}=1.06 \mu \mathrm{M}\right)$, slightly more potent than 5 carrying a 1-naphthyl function $\left(\mathrm{IC}_{50}=4.02 \mu \mathrm{M}\right)$. The corresponding flavanone-benzophenone analogues 6 and 7, respectively, maintained the same trend of inhibition, and again the 3,4,5-trimethoxyphenyl ring allowed compounds to achieve a more favorable enzyme inhibition with respect to the naphthyl ring.

\subsubsection{Neuroprotection}

The neuroprotective potential was investigated for selected compounds $\mathbf{3}-\mathbf{5}$ bearing the metal chelating pharmacophore (ortho-hydroxycarbonylaryl), by evaluating: (a) the neurotoxic effects; (b) the $\mathrm{Cu}$ (II) chelation ability; (c) the antioxidant properties.

\section{Neurotoxicity}

Cytotoxic effects in several in vitro or in vivo models have been reported for some chalcones [23]. Therefore, to discriminate the neurotoxic concentrations of the conjugates 3-5 we evaluated the cell viability of human neuronal SH-SY5Y cells after $24 \mathrm{~h}$ treatment with these conjugate at different concentrations $(1.25-40 \mu \mathrm{M})$ using the MTT assay [24]. In our experimental conditions, neurotoxic effects were recorded for acetophenone $3\left(\mathrm{IC}_{50}=10.89 \pm 1.63 \mu \mathrm{M}\right)$ and chalcone 4 $\left(\mathrm{IC}_{50}=23.66 \pm 3.54 \mu \mathrm{M}\right)$ but not for chalcone 5 . Although, conjugate 4 showed some neurotoxic effects, its low-micromolar BACE-1 IC 50 value suggests a reasonably favorable selectivity index SI (around 22). Thus, the presence of an $\alpha, \beta$-unsatured carbonyl fragment seems to positively influence the degree of neuronal toxicity, leading to molecules endowed with a favorable SI.

\section{In Vitro Cu(II) Chelation}

Bathocuproinedisulfonic acid disodium salt (BCS) [25] assay was employed to assess the Cu(II) chelating ability of various concentration of conjugates 3-5 and the disodium salt of ethylene diaminetetraacetic acid, $\left(\mathrm{Na}_{2}\right.$ EDTA, 5-20 $\left.\mu \mathrm{M}\right)$, in the presence of a fixed $40 \mu \mathrm{M}$ dose of $\mathrm{CuSO}_{4}$. Data were expressed as chelating activity percentage (Table 2). The simplified analogue 3 showed only a modest affinity for $\mathrm{Cu}(\mathrm{II})(5 \mu \mathrm{M}, 0.00 \% ; 10 \mu \mathrm{M}, 3.49 \% \pm 1.71 \% ; 20 \mu \mathrm{M}, 5.37 \% \pm 0.16 \%)$, that was improved by the presence in the molecule of the 3-aryl-propen-1-one framework, as in $4(5 \mu \mathrm{M}$, $7.16 \% \pm 0.24 \% ; 10 \mu \mathrm{M}, 10.77 \% \pm 0.82 \% ; 20 \mu \mathrm{M}, 15.07 \% \pm 1.32 \%)$ and $5(5 \mu \mathrm{M}, 9.48 \% \pm 0.64 \% ; 10 \mu \mathrm{M}$, $13.78 \% \pm 1.74 \% ; 20 \mu \mathrm{M}, 19.73 \% \pm 0.30 \%)$.

\section{Total Antioxidant Activity}

The total antioxidant capacity (TAC) of the selected conjugates 3-5, at various concentrations (0.625-10 $\mathrm{MM})$, was determined using the 2,2-diphenyl-1-picrylhydrazyl (DPPH) inhibition assay [24,26]. In this context, no direct antioxidant effect was recorded (data not shown). Taking into account all these preliminary results, conjugate 5 , endowed with the best neuronal compatibility and $\mathrm{Cu}$ (II) chelating ability, represents the most promising compound of the series, worth of further investigation regarding its neuroprotective action, in particular the mechanism of action by which 5 may exert its antioxidant activity. 
Inhibition of $\mathrm{Cu}(\mathrm{II})$-Mediated ROS Formation

Our attention was then focused on the study of the intracellular antioxidant effect mediated by $\mathrm{Cu}$ (II) chelation. Therefore, compound 5 was selected to be studied in SH-SH5Y cells for its ability to counteract ROS formation elicited by Fenton reaction with $\mathrm{CuSO}_{4}(25 \mu \mathrm{M})$ and $\mathrm{H}_{2} \mathrm{O}_{2}(100 \mu \mathrm{M})$, and using $2^{\prime}, 7^{\prime}$-dichlorodihydrofluorescein diacetate $\left(\mathrm{H}_{2} \mathrm{DCF}-\mathrm{DA}\right)$ as the fluorescent probe [27]. As shown in Figure 2, the conjugate 5 at 5 and $10 \mu \mathrm{M}$ significantly decreased the ROS formation evoked by $\mathrm{H}_{2} \mathrm{O}_{2} / \mathrm{CuSO}_{4}$, expressed as arbitrary fluorescence units (AUF). This finding suggests the ability of 5 to stop the Fenton reaction through the $\mathrm{Cu}(\mathrm{II})$ chelation.

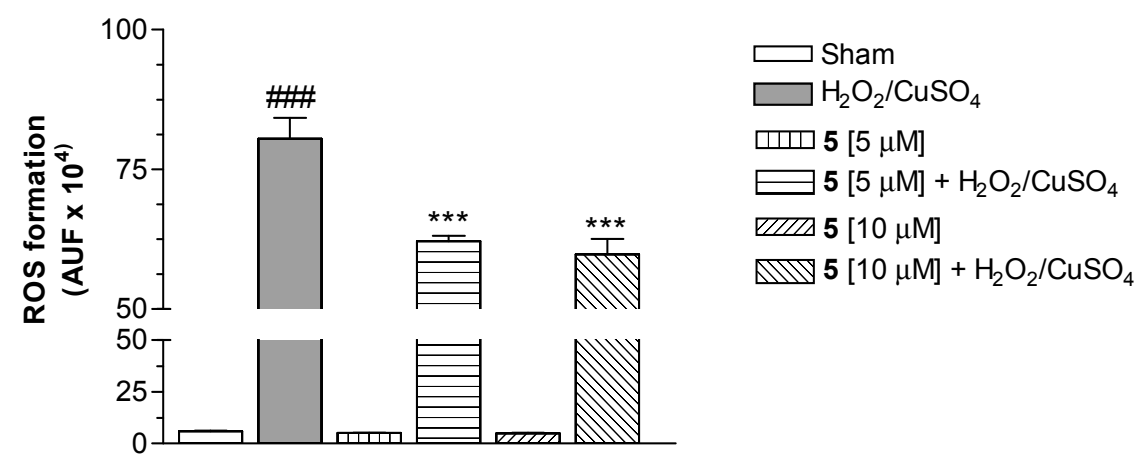

Figure 2. Effect of compound 5 on ROS formation elicited by $\mathrm{H}_{2} \mathrm{O}_{2} / \mathrm{CuSO}_{4}$ in SH-SY5Y cells. The cells were treated with various concentrations of 5 and $\mathrm{H}_{2} \mathrm{O}_{2}(100 \mu \mathrm{M}) / \mathrm{CuSO}_{4}(25 \mu \mathrm{M})$ for $30 \mathrm{~min}$. At the end of the incubation, intracellular ROS formation was determined using a fluorescence probe, as described in the Materials and Methods section. The arbitrary units of fluorescence (AUF) values are shown as mean \pm SD of at least three independent experiments (\#\#\# $P<0.001$ versus untreated cells, *** $P<0.001$ versus cells treated with $\mathrm{H}_{2} \mathrm{O}_{2} / \mathrm{CuSO}_{4}$, at ANOVA with Bonferroni's Post Hoc Test).

\subsection{Spectrophotometric Evaluation of $\mathrm{Cu}(\mathrm{II})$ Ion Complexation}

Chalcone conjugates 4 and 5 were investigated to evaluate their ability to complex $\mathrm{Cu}(\mathrm{II})$ ions via a UV-vis spectrophotometric study. The spectra, reported in Figure 3, showed that both compounds were able to chelate the selected ion.

Flavonoids, in general, and ortho-hydroxychalcones in particular, thanks to their weak acidic character, could be able to complex metal cations with more than one coordination site [11]. Therefore, their affinity for the different metal ions strongly depends on the medium and $\mathrm{pH}$. To experimentally confirm via spectroscopic measurements the $\mathrm{Cu}(\mathrm{II})$ chelation effect observed in the physiological environment for the selected chalcone conjugates 4 and 5, we had to choose a medium that could somehow mimic this very complex situation, taking into account the solubility constrains as well. In alkaline media there is maximum deprotonation, but precipitation equilibria of $\mathrm{Cu}$ (II) hydroxide cannot be easily excluded and controlled.

Therefore, we decided to carry on the spectrophotometric measurements in a mixed solvent: aqueous MOPS aqueous buffer $1 \times 10^{-2} \mathrm{M} \mathrm{pH}$ 7.4 /DMF in 1:4 ratio, respectively. Flavonoids bearing the 4-carbonyl-5-hydroxyl chelation site have characteristic UV-vis spectra, characterized by a wide and non-structured band centred around $370-380 \mathrm{~nm}$, with a molar extinction coefficient of $50,000 \mathrm{~cm}^{-1} \cdot \mathrm{M}^{-1}$ that is attributed to HOMO-LUMO transition with a $\pi-\pi^{*}$ character. 


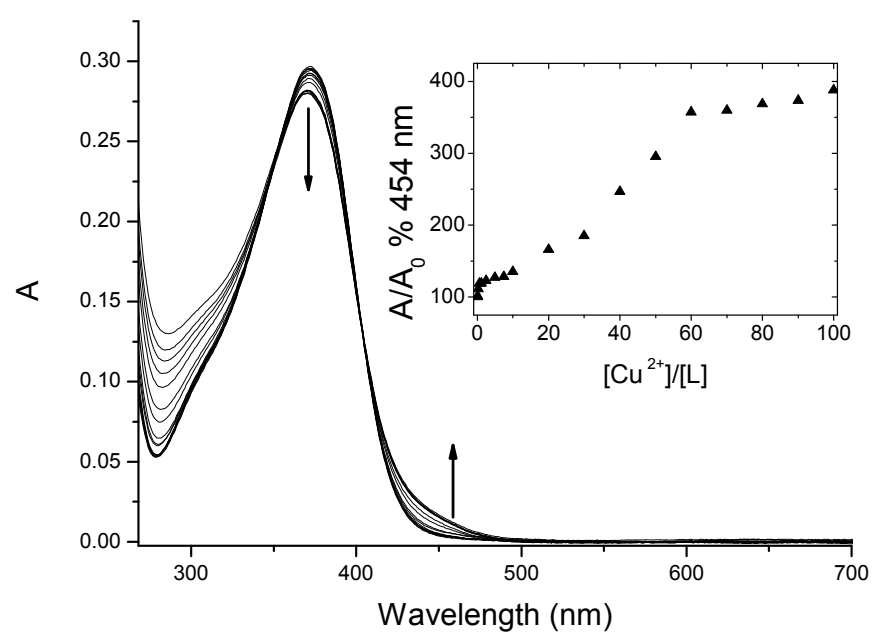

(a)

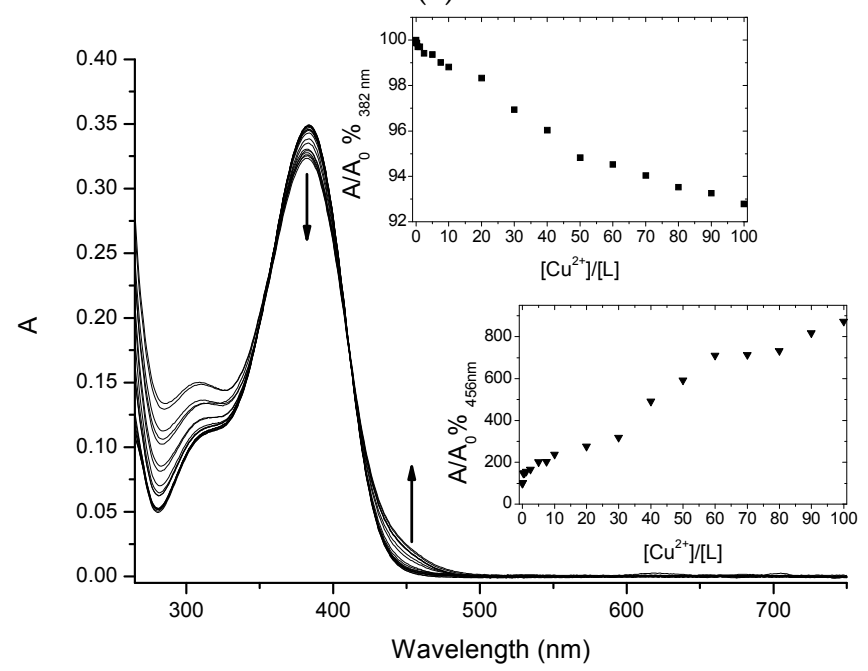

(b)

Figure 3. Titration curves of 4 (a) and 5 (b) (at $5 \mu \mathrm{M}$ concentration) with increasing amounts of $\mathrm{Cu}$ (II) in MOPS $10 \mathrm{mM} \mathrm{pH} \mathrm{7.4/DMF} \mathrm{(1:4).} \mathrm{Inset:} \mathrm{absorbance} \mathrm{ratio} \mathrm{at} 382 \mathrm{~nm}$ versus $\mathrm{Cu}(\mathrm{II})$ equivalents.

The addition of increasing amounts of $\mathrm{Cu}(\mathrm{II})$ ions in solution caused a decrease of the maximum of this band for both ligands, with a concomitant increase of the absorbance around $450 \mathrm{~nm}$. These changes are quite small, but in line with other similar systems already reported in the literature, and therefore diagnostic for the copper complex formation [28].

Chalcones 4 and 5 underwent a UV-vis spectrophotometric study to evaluate their ability to complex $\mathrm{Cu}$ (II) ions and the spectra were reported in Figures 3 and 4. It is important to underline that chalcones, being multi-site metal cation binders, can generate complexes with different stoichiometries and/or structures, thus it is difficult to discriminate among them only via spectrophotometric measurements. Nevertheless, for both selected compounds during the titration procedure we observed the formation of an isosbestic point (402 nm for 4 and $410 \mathrm{~nm}$ for 5, Figure 3a,b, respectively); this feature is a clear indication that the complexation is taking place, even if it does not exclude multiple equilibria involving different metal to ligand stoichiometries (as possibly suggested by the profile of the inset of Figure 3). 

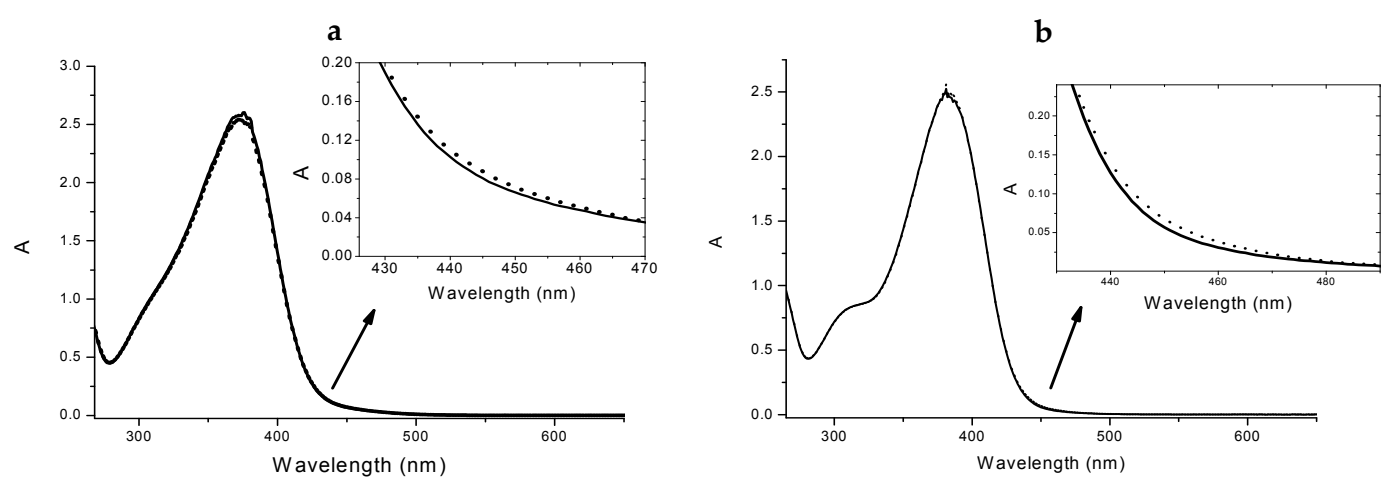

Figure 4. Absorption spectra of $44 \times 10^{-5} \mathrm{M}$ in absence (solid line) and in presence (dotted line) of $2.5 \times 10^{-5} \mathrm{M} \mathrm{Cu}$ (II) (a). Inset: spectral detail of the changing upon the addiction of the metal. Absorption spectra of $54 \times 10^{-5} \mathrm{M}$ in absence (solid line) and in presence (dotted line) of $2.5 \times 10^{-5} \mathrm{M}$ $\mathrm{Cu}(\mathrm{II})(\mathbf{b})$. Inset: spectral detail.

Furthermore, from the titration data an association constant was estimated that was of the order of magnitude of $10^{4}$ for a 1:1 complex stoichiometry. Undoubtedly, the complex cellular environment could drastically influence the binding events, thus any structure prediction could be very difficult; however, the study of the interactions performed in a simpler but similar surrounding could offer very informative experimental evidences. In the light of these considerations, we have studied three different concentrations of each ligand, reproducing the conditions of the biological study. As expected from the titration results, for both 4 and 5 we observed the formation of the complexes as shown in Figure 4 (data not shown for the other concentrations).

\section{Discussion}

Molecules able to modulate a single protein target prove to be ineffective for treatement of multifactorial and complex disorders such as AD. Researchers are now turning to the design of multitarget compounds, single chemical entities able to simultaneously modulate several molecular targets or pathways involved in the disease, since these multipotent compounds could enable to achieve a better efficacy profile compared to the single-target agents. Indeed BACE-1, catalyzing the rate-limiting step in the generation of $A \beta$ fragments, decreases the formation of $A \beta$. On the other hand, $A \beta$ is a metalloprotein that contains metal binding sites, and metals such as copper are present at elevated concentrations in $A \beta$ plaques and can promote the oligomerization of $A \beta$, increasing its cytotoxicity. In this scenario, the "pharmacophores combination" design strategy was applied in this study and two naturally inspired privileged structures, identified as weak BACE-1 inhibitors, were connected. In particular, a benzophenone-based scaffold was conjugated to flavonoid-related frameworks, namely chalcone and flavanone, as metal chelating pharmacophores. The small library of hybrid molecules 3-7 turned out to inhibit BACE-1 enzyme with a low-micromolar potency and the new compounds proved to be more active than the starting hit fragments. Moreover, the chalcone-based analogues 4 and 5 , endowed with an $\alpha, \beta$-unsaturated carbonyl fragment, showed an interesting biological profile in terms of ability to chelate $\mathrm{Cu}$ (II) ions, associated with a lack of neurotoxic effects (favorable selectivity index).

Indeed redox active $\mathrm{Cu}(\mathrm{II})$ in complex with $\mathrm{A} \beta$ can generate $\mathrm{H}_{2} \mathrm{O}_{2}$, which may be converted to hydroxyl radicals via Fenton reaction, resulting in oxidative cellular damage. Taking this into account, $\mathbf{5}$ was also tested as an antioxidant and proved to be able to counteract the $\mathrm{Cu}$ (II)-dependent ROS formation.

Finally, compound 5 proved to be a valuable multifunctional compound, able to protect from common $\mathrm{AD}$ pathogenic events such as $\mathrm{A} \beta$ formation and $\mathrm{Cu}$ injury. It is thus characterized by a low-micromolar inhibitory potency on BACE-1 enzyme, a good $\mathrm{Cu}$ (II) chelating ability (confirmed also by UV-vis spectrophotometric studies) and a consequent efficacy to protect from $\mathrm{Cu}$ (II)-mediated 
toxicity. In summary, our initial design hypothesis was validated by the multipotent biological profile of the benzophenone-chalcone conjugate 5 that represents a new promising lead compound, worth of being further optimized and investigated in terms of structure-activity relationships (SAR). The results of this study can be considered as the basis for the design of new small libraries of hybrids obtained by conjugation of biologically relevant frameworks: the $N, N^{\prime}$-benzylmethylamino-benzophenone scaffold on one side and flavonoid-related frameworks on the other side.

\section{Materials and Methods}

\subsection{General Information}

Starting materials, unless otherwise specified, were high-purity commercial products. Solvents were of analytical grade. Melting points were determined in open glass capillaries, using a Büchi apparatus and are uncorrected. ${ }^{1} \mathrm{H}-\mathrm{NMR}$ and ${ }^{13} \mathrm{C}-\mathrm{NMR}$ spectra were recorded on a Gemini spectrometer (400 MHz Varian, Palo Alto, CA, USA) and chemical shift are reported as parts per million (ppm value) relative to the peak for tetramethylsilane (TMS) as internal standard. Standard abbreviations indicating spin multiplicities are given as follows: $\mathrm{s}$ (singlet), $\mathrm{d}$ (doublet), $\mathrm{t}$ (triplet), br (broad), q (quartet) or m (multiplet). Mass spectra were recorded on a ZQ 4000 apparatus (Waters, Milford, MA, USA) operating in electrospray mode (ES). Chromatographic separations were performed on silica gel columns by the flash method (Kieselgel 40, 0.040-0.063 mm, Merck, Darmstadt, Germany). Reactions were followed by thin layer chromatography (TLC) on precoated silica gel plates (Merck Silica Gel 60 F254) and then visualized with a UV lamp. The purity of the tested compounds was determined by HPLC analysis, performed on a LC 1500 PU-1587 system (Jasco, Easton, MD, USA); the column used was a Luna C18(2) $5 \mathrm{~m} 4.60 \mathrm{~mm} \times 150 \mathrm{~mm}$ (Phenomenex, Castel Maggiore (BO), Italy); elution conditions: $\mathrm{H}_{3} \mathrm{PO}_{4} 0.5 \% / \mathrm{ACN}(75: 25, v / v)$ the flow-rate was $1.2 \mathrm{~mL} / \mathrm{min}$ and the injection volume was $5 \mu \mathrm{L}$; peaks were detected at $254 \mathrm{~nm}$ and results were $>98 \%$ purity. Compounds were named relying on the naming algorithm provided in ChemDraw Professional 15.0, developed by CambridgeSoft Corporation (Waltham, MA, USA).

\subsection{Chemistry}

\subsubsection{General Procedure for the Synthesis of 3-7, 9, 10 by Williamson Reaction}

To a room temperature solution of the phenol derivative $(1.0 \mathrm{mmol})$ in acetone $(10 \mathrm{~mL}) \mathrm{K}_{2} \mathrm{CO}_{3}$ ( $1.1 \mathrm{mmol})$ was added, followed by the corresponding bromoalkyl derivative $(1.0 \mathrm{mmol})$. The reaction mixture was heated under reflux and the reaction progress was monitored by TLC. Upon reaction completion, the mixture was hot filtered, and the solvent was evaporated under reduced pressure. The resulting crude product was purified by column chromatography over a silica gel column using a mixture of petroleum ether/ethyl acetate as the solvent system to give the desired pure products.

1-[2-Hydroxy-4-(2-hydroxyethoxy)phenyl]ethanone (9). Reaction of 2,4-dihydroxyacetophenone (5.0 mmol, $0.76 \mathrm{~g}$ ) and 2-bromoethanol $(5.5 \mathrm{mmol}, 0.69 \mathrm{~g}, 0.39 \mathrm{~mL})$ gave the crude product that was purified by flash chromatography (petroleum ether/ethyl acetate $7 / 3)$.Yield $=85 \%$, mp: $64-66{ }^{\circ} \mathrm{C} .{ }^{1} \mathrm{H}-\mathrm{NMR}\left(\mathrm{CDCl}_{3}\right)$ $\delta 2.56\left(\mathrm{~s}, 3 \mathrm{H}, \mathrm{COCH}_{3}\right), 3.95-4.01\left(\mathrm{~m}, 2 \mathrm{H}, \mathrm{CH}_{2} \mathrm{OH}\right), 4.10-4.14\left(\mathrm{~m}, 2 \mathrm{H}, \mathrm{OCH}_{2}\right), 6.40(\mathrm{~d}, J=1.8 \mathrm{~Hz}, 1 \mathrm{H}$, ArH-3), $6.50(\mathrm{dd}, J=1.8$ and $8.6 \mathrm{~Hz}, 1 \mathrm{H}, \mathrm{ArH}-5), 7.64(\mathrm{~d}, J=8.6 \mathrm{~Hz}, 1 \mathrm{H}, \mathrm{ArH}-6)$.

1-[2-Hydroxy-4-(2-bromoethoxy)phenyl]ethan-1-one (10). Reaction of 2,4-dihydroxyacetophenone (5.0 mmol, $0.76 \mathrm{~g}$ ) and 1,2-dibromoethane $(5.0 \mathrm{mmol}, 0.94 \mathrm{~g}, 0.45 \mathrm{~mL})$, gave the crude product that was purified by flash chromatography (petroleum ether/ethyl acetate 4:1). Yield = 85\%, mp: 61-63 ${ }^{\circ} \mathrm{C}$. ${ }^{1} \mathrm{H}-\mathrm{NMR} \delta: 2.60\left(\mathrm{~s}, 3 \mathrm{H}, \mathrm{COCH}_{3}\right), 3.83\left(\mathrm{t}, 2 \mathrm{H}, J=6.00 \mathrm{~Hz}, \mathrm{CH}_{2} \mathrm{Br}\right), 4.26\left(\mathrm{t}, 2 \mathrm{H}, J=6.00 \mathrm{~Hz}, \mathrm{OCH}_{2}\right), 6.40$ $(\mathrm{d}, J=2.2 \mathrm{~Hz}, 1 \mathrm{H}, \mathrm{ArH}-3) 6.48(\mathrm{dd}, J=8.0$ and $2.2 \mathrm{~Hz}, 1 \mathrm{H}, \mathrm{ArH}-5), 7.65(\mathrm{~d}, 1 \mathrm{H}, J=9.20 \mathrm{~Hz}, \mathrm{ArH}-6)$.

1-\{4-[2-(4-4-Benzylmethylaminomethylbenzoylphenoxy)ethoxy]-2-hydroxyphenyl\}ethan-1-one (3). Reaction of benzophenone $(\mathrm{Bp}) \mathbf{8}(1.0 \mathrm{mmol}, 0.33 \mathrm{~g})$ and $10(1.1 \mathrm{mmol}, 0.28 \mathrm{~g})$ gave a crude product that was purified 
by flash chromatography $\left(\mathrm{CH}_{2} \mathrm{Cl}_{2} / \mathrm{CH}_{3} \mathrm{OH}\right.$ 9.5:0.5) to give a semisolid compound, Yield $=51 \%$, $\mathrm{HCl}$; mp: 264-268 ${ }^{\circ} \mathrm{C} .{ }^{1} \mathrm{H}-\mathrm{NMR}\left(400 \mathrm{MHz}, \mathrm{CDCl}_{3}\right) \delta 2.33\left(\mathrm{~s}, 3 \mathrm{H}, \mathrm{NCH}_{3}\right), 2.55\left(\mathrm{~s}, 3 \mathrm{H}, \mathrm{COCH}_{3}\right), 3.56(\mathrm{~s}, 2 \mathrm{H}$, $\left.\mathrm{NCH}_{2}\right), 3.59\left(\mathrm{~s}, 2 \mathrm{H}, \mathrm{NCH}_{2}\right), 3.90-3.94\left(\mathrm{~m}, 4 \mathrm{H}, \mathrm{OCH}_{2} \mathrm{CH}_{2} \mathrm{O}\right), 6.48(\mathrm{~d}, J=2.2 \mathrm{~Hz}, 1 \mathrm{H}, \mathrm{Ch}-\mathrm{Ar}), 6.51$ (dd, $J=8.0$ and $2.2 \mathrm{~Hz}, 1 \mathrm{H}, \mathrm{Ch}-\mathrm{Ar}), 7.00(\mathrm{~d}, 2 \mathrm{H}, J=8.40 \mathrm{~Hz}, \mathrm{Bf}-\mathrm{Ar}), 7.26-7.46(\mathrm{~m}, 5 \mathrm{H}, \mathrm{Bn}-\mathrm{Ar}), 7.49$ $(\mathrm{d}, 2 \mathrm{H}, J=8.60 \mathrm{~Hz}, \mathrm{Bf}-\mathrm{Ar}), 7.63(\mathrm{~d}, 1 \mathrm{H}, J=8.0 \mathrm{~Hz}, \mathrm{Ch}-\mathrm{Ar}), 7.75(\mathrm{~d}, 2 \mathrm{H}, J=8.60 \mathrm{~Hz}, \mathrm{Bf}-\mathrm{Ar}), 7.85$ (d, $2 \mathrm{H}, J=8.60 \mathrm{~Hz}, \mathrm{Bf}-\mathrm{Ar}) .{ }^{13} \mathrm{C}-\mathrm{NMR}\left(101 \mathrm{MHz}, \mathrm{CDCl}_{3}\right): \delta 26.64,61.055,61.62,64.34,64.66,103.87,106.98$, 113.44, 126.90, 128.12, 128.52, 128.74, 128.86, 129.77, 130.41, 132.41, 136.91, 138.22, 143.69, 162.59, 165.11, 166.65, 197.56, 202.61. $\left(\mathrm{ESI}^{+}\right) 510 \mathrm{~m} / z:[\mathrm{M}+\mathrm{H}]^{+}$.

E-1-\{4-[2-(4-4-Benzylmethylaminomethylbenzoylphenoxy)ethoxy]-2-hydroxyphenyl\}-3-(3,4,5-trimethoxyphenyl)prop-2-en-1-one (4). Reaction of Bp 8 (1.0 mmol, $0.33 \mathrm{~g})$ and chalcone (Ch) 11 (1.1 mmol, $0.48 \mathrm{~g})$ gave a crude product that was purified by flash chromatography $\left(\mathrm{CH}_{2} \mathrm{Cl}_{2} / \mathrm{CH}_{3} \mathrm{OH}\right.$ 9.25:0.75) to give a semisolid compound. Yield $=65 \%, \mathrm{HCl}$; mp: $220-222{ }^{\circ} \mathrm{C} .{ }^{1} \mathrm{H}-\mathrm{NMR}\left(400 \mathrm{MHz}, \mathrm{CDCl}_{3}\right) \delta 2.30(\mathrm{~s}, 3 \mathrm{H}$, $\left.\mathrm{NCH}_{3}\right), 3.57\left(\mathrm{~s}, 2 \mathrm{H}, \mathrm{NCH}_{2}\right), 3.59\left(\mathrm{~s}, 2 \mathrm{H}, \mathrm{NCH}_{2}\right), 3.91\left(\mathrm{~s}, 3 \mathrm{H}, \mathrm{OCH}_{3}\right), 3.94\left(\mathrm{~s}, 6 \mathrm{H}, \mathrm{OCH}_{3}\right), 4.20-4.34$ $\left(\mathrm{m}, 4 \mathrm{H}, \mathrm{OCH}_{2} \mathrm{CH}_{2} \mathrm{O}\right), 6.50(\mathrm{~d}, J=2.2 \mathrm{~Hz}, 1 \mathrm{H}, \mathrm{Ch}-\mathrm{Ar}), 6.54(\mathrm{dd}, J=8.0$ and $2.2 \mathrm{~Hz}, 1 \mathrm{H}, \mathrm{Ch}-\mathrm{Ar}), 6.87$ (s, 2H, Ch-Ar), $7.00(\mathrm{~d}, 2 \mathrm{H}, J=8.60 \mathrm{~Hz}, \mathrm{Bp}-\mathrm{Ar}), 7.16-7.36(\mathrm{~m}, 5 \mathrm{H}, \mathrm{Bn}-\mathrm{Ar}), 7.26(\mathrm{~d}, 1 \mathrm{H}, J=15.60 \mathrm{~Hz}$, Ch- $\beta \mathrm{CH}=\mathrm{CH}), 7.72(\mathrm{~d}, 2 \mathrm{H}, J=8.60 \mathrm{~Hz}, \mathrm{Ch}-\mathrm{Ar}), 7.78(\mathrm{~d}, 1 \mathrm{H}, J=8.60 \mathrm{~Hz}, \mathrm{Bp}-\mathrm{Ar}), 7.85(\mathrm{~d}, 1 \mathrm{H}, J=15.60 \mathrm{~Hz}$, Ch- $\alpha \mathrm{CH}=\mathrm{CH}), 7.88(\mathrm{~d}, 2 \mathrm{H}, J=8.60 \mathrm{~Hz}, \mathrm{Bp}-\mathrm{Ar}) ;{ }^{13} \mathrm{C}-\mathrm{NMR}\left(101 \mathrm{MHz}, \mathrm{CDCl}_{3}\right): \delta 56.11,60.85,64.34$, 64.66, 103.86, 106.93, 113.45, 118.74, 126.96, 128.17, 128.56, 128.71, 128.80, 129.70, 130.46, 132.45, $136.92,138.24,143.68,145.32,153.01,153.22,162.5,165.11,166.62,197.58,192.41 .\left(\mathrm{ESI}^{+}\right) \mathrm{m} / z: 687[\mathrm{M}+\mathrm{H}]^{+}$.

E-1-\{4-[2-(4-4-Benzylmethylaminomethylbenzoylphenoxy)ethoxy]-2-hydroxyphenyl\}-3-(naphthalen-1-yl)prop-2-en-1-one (5). Reaction of Bp 8 (1.0 mmol, $0.33 \mathrm{~g})$ and $\mathrm{Ch} 12$ (1.1 mmol, $0.44 \mathrm{~g})$ gave a crude product that was purified by flash chromatography $\left(\mathrm{CH}_{2} \mathrm{Cl}_{2} / \mathrm{CH}_{3} \mathrm{OH}\right.$ 9.25:0.75) to give a semisolid compound. Yield $=51 \%$, HCl: mp: $197-99{ }^{\circ} \mathrm{C} .{ }^{1} \mathrm{H}-\mathrm{NMR}\left(400 \mathrm{MHz}, \mathrm{CDCl}_{3}\right) \delta 2.32\left(\mathrm{~s}, 3 \mathrm{H}, \mathrm{NCH}_{3}\right), 3.59$ (s, $\left.2 \mathrm{H}, \mathrm{NCH}_{2}\right), 3.62\left(\mathrm{~s}, 2 \mathrm{H}, \mathrm{NCH}_{2}\right), 4.30-4.40\left(\mathrm{~m}, 4 \mathrm{H}, \mathrm{OCH}_{2} \mathrm{CH}_{2} \mathrm{O}\right), 6.55(\mathrm{~d}, J=2.2 \mathrm{~Hz}, 1 \mathrm{H}, \mathrm{Ch}-\mathrm{Ar}), 6.58$ $(\mathrm{dd}, J=8.0$ and $2.2 \mathrm{~Hz}, 1 \mathrm{H}, \mathrm{Ch}-\mathrm{Ar}), 7.02(\mathrm{~d}, 2 \mathrm{H}, J=8.60 \mathrm{~Hz}, \mathrm{Bf}-\mathrm{Ar}), 7.20-7.61(\mathrm{~m}, 10 \mathrm{H}, \mathrm{Ar}), 7.75(\mathrm{~d}, 1 \mathrm{H}$, $J=16.4 \mathrm{~Hz}, \beta-\mathrm{CH}=\mathrm{CH}), 7.79-7.97(\mathrm{~m}, 8 \mathrm{H}, \mathrm{Ar}), 8.03(\mathrm{~d}, 1 \mathrm{H}, J=8.0 \mathrm{~Hz}, \mathrm{Ch}-\mathrm{Ar}), 8.75(\mathrm{~d}, 1 \mathrm{H}, J=15.60 \mathrm{~Hz}$, $\alpha \mathrm{CH}=\mathrm{CH}) ;{ }^{13} \mathrm{C}$ NMR $\left(101 \mathrm{MHz}, \mathrm{CDCl}_{3}\right): \delta 61.05,61.62,64.34,64.66,103.88,106.96,113.44,121.33$, $122.85,126.14,126.99,128.19,128.51,128.76,128.83,129.72,130.43,132.48,132.47,133.54,135.54,136.94$, $138.23,143.63,162.59,165.11,166.65,197.50,192.81 .\left(\mathrm{ESI}^{+}\right) \mathrm{m} / \mathrm{z}: 648[\mathrm{M}+\mathrm{H}]^{+}$.

7-\{2-[4-(4-Benzylmethylaminomethylbenzoyl)phenoxy]ethoxy\}-2-(3,4,5-trimethoxyphenyl)chroman-4-one (6). Reaction of Bp $8(1.0 \mathrm{mmol}, 0.33 \mathrm{~g})$ and flavone (Fl) $13(1.1 \mathrm{mmol}, 0.48 \mathrm{~g})$ gave a crude product that was purified by flash chromatography $\left(\mathrm{CH}_{2} \mathrm{Cl}_{2} / \mathrm{CH}_{3} \mathrm{OH}\right.$ 9.5:0.5) to give a semisolid compound. Yield $=59 \%, \mathrm{HCl}: \mathrm{mp}: 182-94{ }^{\circ} \mathrm{C} .{ }^{1} \mathrm{H}-\mathrm{NMR}\left(400 \mathrm{MHz}, \mathrm{CDCl}_{3}\right) \delta 2.32\left(\mathrm{~s}, 3 \mathrm{H}, \mathrm{NCH}_{3}\right), 2.87(\mathrm{dd}, 1 \mathrm{H}$, $J=16.5$ and $2.8 \mathrm{~Hz}, \mathrm{H} 3 \mathrm{a}-\mathrm{Fl}), 3.06(\mathrm{dd}, 1 \mathrm{H}, J=16.5$ and $13.1 \mathrm{~Hz}, \mathrm{H} 3 \mathrm{~b}-\mathrm{Fl}) 3.70\left(\mathrm{~s}, 2 \mathrm{H}, \mathrm{NCH}_{2}\right), 3.74(\mathrm{~s}, 2 \mathrm{H}$, $\left.\mathrm{NCH}_{2}\right), 3.87\left(\mathrm{~s}, 3 \mathrm{H}, \mathrm{OCH}_{3}\right), 3.90\left(\mathrm{~s}, 6 \mathrm{H}, \mathrm{OCH}_{3}\right), 4.40-4.46\left(\mathrm{~m}, 4 \mathrm{H}, \mathrm{OCH}_{2} \mathrm{CH}_{2} \mathrm{O}\right), 5.37(\mathrm{dd}, 1 \mathrm{H}, J=13.1$ and $2.8 \mathrm{~Hz}, \mathrm{H} 2-\mathrm{Fl}), 6.57(\mathrm{~d}, J=2.2 \mathrm{~Hz}, 1 \mathrm{H}, \mathrm{Fl}-\mathrm{Ar}), 6.70(\mathrm{dd}, J=8.0$ and $2.2 \mathrm{~Hz}, 1 \mathrm{H}, \mathrm{Fl}-\mathrm{Ar}), 6.75(\mathrm{~s}, 2 \mathrm{H}$, Fl-Ar), 7.00 (d, 2H, J = 8.60 Hz, Bf-Ar), 7.26-7.36 (m, 5H, Bn-Ar), 7.78 (d, 1H, J = 8.60 Hz, Bf-Ar), 7.81 $(\mathrm{d}, 2 \mathrm{H}, J=8.60 \mathrm{~Hz}, \mathrm{Bf}-\mathrm{Ar}), 7.86$ (d, 2H, $J=8.60 \mathrm{~Hz}, \mathrm{Bf}-\mathrm{Ar}) ;{ }^{13} \mathrm{C}-\mathrm{NMR}\left(101 \mathrm{MHz}, \mathrm{CDCl}_{3}\right): \delta 42.45,56.10$, $59.21,61.05,61.62,64.34,64.66,83.44,101.74,103.86,106.93,113.46,126.98,128.12,128.54,128.76,128.82$, $129.78,130.45,132.43,134.91,136.92,138.22,143.67,153.21,138.74,163.25,165.11,166.65,197.51,190.21$. MS $\left(\mathrm{ESI}^{+}\right) m / z: 689[\mathrm{M}+\mathrm{H}]^{+}$.

7-\{2-[4-(4-(Benzylmethylaminomethylbenzoyl)phenoxy]ethoxy\}-2-(naphthalen-1-yl)chroman-4-one Reaction of Bf $8(1.0 \mathrm{mmol}, 0.33 \mathrm{~g})$ and $\mathrm{Fl} 13(1.1 \mathrm{mmol}, 0.44 \mathrm{~g})$ gave a crude product that was purified by flash chromatography $\left(\mathrm{CH}_{2} \mathrm{Cl}_{2} / \mathrm{CH}_{3} \mathrm{OH}\right.$ 9.5:0.5) to give a semisolid compound. Yield $=45 \%, \mathrm{HCl}$ : mp: $172-95^{\circ} \mathrm{C} .{ }^{1} \mathrm{H}-\mathrm{NMR}\left(400 \mathrm{MHz}, \mathrm{CDCl}_{3}\right) \delta 2.22\left(\mathrm{~s}, 3 \mathrm{H}, \mathrm{NCH}_{3}\right), 3.03(\mathrm{dd}, 1 \mathrm{H}, J=16.5$ and $2.8 \mathrm{~Hz}$, $\mathrm{H} 3 \mathrm{a}-\mathrm{Fl}), 3.26(\mathrm{dd}, 1 \mathrm{H}, J=16.5$ and $13.1 \mathrm{~Hz}, \mathrm{H} 3 \mathrm{~b}-\mathrm{Fl}) 3.54\left(\mathrm{~s}, 2 \mathrm{H}, \mathrm{NCH}_{2}\right), 3.61\left(\mathrm{~s}, 2 \mathrm{H}, \mathrm{NCH}_{2}\right), 4.36-4.48$ $\left(\mathrm{m}, 4 \mathrm{H}, \mathrm{OCH}_{2} \mathrm{CH}_{2} \mathrm{O}\right), 6.21(\mathrm{dd}, 1 \mathrm{H}, J=13.1$ and $\left.2.8 \mathrm{~Hz}, \mathrm{H} 2-\mathrm{Fl}),\right), 6.57(\mathrm{~d}, J=2.2 \mathrm{~Hz}, 1 \mathrm{H}, \mathrm{Fl}-\mathrm{Ar}), 6.58$ $(\mathrm{dd}, J=8.0$ and $2.2 \mathrm{~Hz}, 1 \mathrm{H}, \mathrm{Fl}-\mathrm{Ar}), 7.02(\mathrm{~d}, 2 \mathrm{H}, J=8.60 \mathrm{~Hz}, \mathrm{Bf}-\mathrm{Ar}), 7.20-7.61(\mathrm{~m}, 10 \mathrm{H}, \mathrm{Ar}), 7.79-7.97(\mathrm{~m}$, 
$8 \mathrm{H}, \mathrm{Ar}), 8.05(\mathrm{~d}, 1 \mathrm{H}, J=8.0 \mathrm{~Hz}, \mathrm{Fl}-\mathrm{Ar}) .{ }^{13} \mathrm{C}-\mathrm{NMR}\left(101 \mathrm{MHz}, \mathrm{CDCl}_{3}\right): \delta 43.21,61.05,61.62,64.34$, $64.66,80.80,103.81,106.93,113.09,113.43,125.47,126.41,126.97,128.17,128.53,128.78,128.89,129.79$, $130.49,132.45,134.98,136.31,136.95,138.21,136.88,143.63,162.57,163.25,165.11,166.65,197.57,190.66$. MS $\left(\mathrm{ESI}^{+}\right) m / z: 649[\mathrm{M}+\mathrm{H}]^{+}$.

\subsubsection{General Procedure for the Synthesis of Chalcones 2, 11, 12 by Claisen-Schmidt Reaction}

To a solution of acetophenone $(1.0 \mathrm{mmol})$ and substituted benzaldehyde $(1.1 \mathrm{mmol})$ in ethanol $(10 \mathrm{~mL}), 50 \% \mathrm{KOH}$ aqueous solution $(3.0 \mathrm{mmol}, 0.11 \mathrm{~mL})$ was added dropwise. The reaction mixture was stirred at r.t. overnight, then diluted with water and acidified with $6 \mathrm{~N} \mathrm{HCl}$. The solid formed was collected by vacuum filtration and the crude residue was purified by flash column chromatography or by crystallization from ethanol.

(E)-1-[2-Hydroxy-4-(2-hydroxyethoxyphenyl)]-3-(3,4,5-trimethoxyphenyl)prop-2-en-1-one (2). Reaction of $9(1.0 \mathrm{mmol}, 0.19 \mathrm{~g})$ and 3,4,5-trimethoxybenzaldehyde $(1.1 \mathrm{mmol}, 0.22 \mathrm{~g})$ gave a crude that was purified by flash chromatography (petroleum ether/ethyl acetate 7:3) to afford 2 as a yellowish solid. Yield $=71 \%$, mp: $186-188^{\circ} \mathrm{C} .{ }^{1} \mathrm{H}-\mathrm{NMR}\left(\mathrm{CDCl}_{3}\right) \delta 3.91\left(\mathrm{~s}, 3 \mathrm{H}, \mathrm{OCH}_{3}\right), 3.94\left(\mathrm{~s}, 6 \mathrm{H}, \mathrm{OCH}_{3}\right), 4.00(\mathrm{t}$, $\left.J=6.0 \mathrm{~Hz}, 2 \mathrm{H}, \mathrm{CH}_{2} \mathrm{OH}\right), 4.13\left(\mathrm{t}, J=6.0 \mathrm{~Hz}, 2 \mathrm{H}, \mathrm{OCH}_{2}\right), 6.47(\mathrm{~d}, J=2.2 \mathrm{~Hz}, 1 \mathrm{H}$ and $\mathrm{H} 3), 6.52(\mathrm{dd}$, $J=2.2$ and $8.2 \mathrm{~Hz}, 1 \mathrm{H}$ and $\mathrm{H} 5), 6.87\left(\mathrm{~s}, 2 \mathrm{H}, \mathrm{H}^{\prime}\right.$ and $\left.\mathrm{H}^{\prime}\right), 7.45(\mathrm{~d}, J=15.4 \mathrm{~Hz}, 1 \mathrm{H}, \beta \mathrm{CH}=\mathrm{CH}), 7.78(\mathrm{~d}$, $J=15.4 \mathrm{~Hz}, 1 \mathrm{H}, \alpha \mathrm{CH}=\mathrm{CH}), 7.84(\mathrm{~d}, 1 \mathrm{H}, J=8.6 \mathrm{~Hz}, \mathrm{H} 6) .{ }^{13} \mathrm{C}-\mathrm{NMR}\left(\mathrm{CDCl}_{3}\right) \delta 56.23,56.28,60.33,66.43$, 79.51, 101.74, 105.81, 118.35, 118.44, 121.09, 121.26, 136.63, 136.66, 145.41, 147.48, 165.90, 166.64, 192.85 . MS $\left(\mathrm{ESI}^{+}\right) \mathrm{m} / z: 375[\mathrm{M}+\mathrm{H}]^{+}$.

(E)-1-[4-(2-Bromoethoxy)-2-hydroxyphenyl]-3-(3,4,5-trimethoxyphenyl)prop-2-en-1-one (11). Reaction of $10(1.0 \mathrm{mmol}, 0.26 \mathrm{~g})$ and 3,4,5-trimethoxybenzaldehyde $(1.1 \mathrm{mmol}, 0.22 \mathrm{~g})$ gave a crude that was purified by crystallization from ethanol to afford 11 as a yellowish solid. Yield $=91 \%$, mp: $170-172{ }^{\circ} \mathrm{C}$. ${ }^{1} \mathrm{H}-\mathrm{NMR} \delta 3.35\left(\mathrm{t}, 2 \mathrm{H}, J=6.6, \mathrm{CH}_{2}-\mathrm{Br}\right), 3.80\left(\mathrm{~s}, 3 \mathrm{H}, \mathrm{OCH}_{3}\right), 3.84\left(\mathrm{~s}, 6 \mathrm{H}, \mathrm{OCH}_{3}\right), 4.15(\mathrm{t}, 2 \mathrm{H}, J=6.6 \mathrm{~Hz}$, $\left.\mathrm{OCH}_{2}\right), 6.45(\mathrm{~d}, 1 \mathrm{H}, J=2.2 \mathrm{~Hz}, \mathrm{H} 3), 6.54(\mathrm{dd}, 1 \mathrm{H}, J=2.2$ and $8.2 \mathrm{~Hz}, \mathrm{H} 5), 6.88\left(\mathrm{~s}, 2 \mathrm{H}, \mathrm{H} 2^{\prime}\right.$ and $\left.\mathrm{H}^{\prime}\right), 7.43$ $(\mathrm{d}, 1 \mathrm{H}, J=15.6 \mathrm{~Hz}, \beta \mathrm{CH}=\mathrm{CH}), 7.82(\mathrm{~d}, J=15.6 \mathrm{~Hz}, 1 \mathrm{H}, \alpha \mathrm{CH}=\mathrm{CH}), 7.88(\mathrm{~d}, 1 \mathrm{H}, J=8.6 \mathrm{~Hz}, \mathrm{H6})$.

(E)-1-(4-(2-Bromoethoxy)-2-hydroxyphenyl)-3-(naphthalen-1-yl)prop-2-en-1-one (12). Reaction of 10 $(1.0 \mathrm{mmol}, 0.26 \mathrm{~g})$ and 1-naphthaldehyde $(1.1 \mathrm{mmol}, 0.16 \mathrm{~g})$ gave a crude that was purified by crystallization from ethanol to afford 12 as a yellowish solid. Yield $89 \%, \mathrm{mp}: 140-142{ }^{\circ} \mathrm{C}$. ${ }^{1} \mathrm{H}-\mathrm{NMR} \delta$ $3.36\left(\mathrm{t}, 2 \mathrm{H}, J=6.8, \mathrm{CH}_{2}-\mathrm{Br}\right), 4.18\left(\mathrm{t}, 2 \mathrm{H}, J=6.8 \mathrm{~Hz}, \mathrm{OCH}_{2}\right), 6.46(\mathrm{~d}, 1 \mathrm{H}, J=2.2 \mathrm{~Hz}, \mathrm{H} 3), 6.51(\mathrm{dd}, 1 \mathrm{H}$, $J=2.2$ and $8.2 \mathrm{~Hz}, \mathrm{H} 5), 7.51-7.64(\mathrm{~m}, 3 \mathrm{H}, \mathrm{Ar}), 7.65(\mathrm{~d}, 1 \mathrm{H}, J=15.3 \mathrm{~Hz}, \beta \mathrm{CH}=\mathrm{CH}), 7.86-7.96(\mathrm{~m}, 4 \mathrm{H}$, Ar), $7.87(\mathrm{~d}, 1 \mathrm{H}, J=8.6 \mathrm{~Hz}, \mathrm{H6}), 8.25(\mathrm{~d}, J=15.6 \mathrm{~Hz}, 1 \mathrm{H}, \alpha \mathrm{CH}=\mathrm{CH})$.

\subsubsection{General Procedure for the Synthesis of Flavanones 13, 14.}

Chalcone $(0.5 \mathrm{mmol})$ and sodium acetate $(5.0 \mathrm{mmol})$ were dissolved in ethanol $(10 \mathrm{~mL})$ and the solution was heated under reflux for $24 \mathrm{~h}$. The reaction mixture was allowed to cool to r.t. and then poured into ice/water $(100 \mathrm{~mL})$, and extracted with $\mathrm{CH}_{2} \mathrm{Cl}_{2}(3 \times 30 \mathrm{~mL})$. The combined organic layers were washed with brine, dried over $\mathrm{Na}_{2} \mathrm{SO}_{4}$, and concentrated under reduced pressure. The crude residue was purified by column chromatography using petroleum ether/ethyl acetate (7:3) as solvent system, to afford the pure flavanone.

7-(2-Bromoethoxy)-2-(3,4,5-trimethoxyphenyl)chroman-4-one (13). From the reaction of $\mathbf{1 1}(0.5 \mathrm{mmol}, 0.20 \mathrm{~g})$ and $\mathrm{NaOAc}(5.0 \mathrm{mmol}, 0.04 \mathrm{~g}), 13$ was obtained as pale yellow solid. Yield $48 \%, \mathrm{mp}: 132-133{ }^{\circ} \mathrm{C}$. ${ }^{1} \mathrm{H}-\mathrm{NMR} \delta 2.89(\mathrm{dd}, 1 \mathrm{H}, J=16.5$ and $2.8 \mathrm{~Hz}, \mathrm{H} 3 \mathrm{a}), 3.11(\mathrm{dd}, 1 \mathrm{H}, J=16.5$ and $13.1 \mathrm{~Hz}, \mathrm{H} 3 \mathrm{~b}), 3.35$ (t, $\left.2 \mathrm{H}, J=6.6, \mathrm{CH}_{2}-\mathrm{Br}\right), 4.26\left(\mathrm{t}, 2 \mathrm{H}, J=6.6 \mathrm{~Hz}, \mathrm{OCH}_{2}\right), 5.51(\mathrm{dd}, 1 \mathrm{H}, J=13.1$ and $2.8 \mathrm{~Hz}, \mathrm{H} 2), 6.43(\mathrm{~d}, 1 \mathrm{H}$, $J=2.2 \mathrm{~Hz}, \mathrm{H} 3), 6.57(\mathrm{dd}, 1 \mathrm{H}, J=2.2$ and $8.2 \mathrm{~Hz}, \mathrm{H} 5), 6.91\left(\mathrm{~s}, 2 \mathrm{H}, \mathrm{H} 2^{\prime}\right.$ and $\left.\mathrm{H6}^{\prime}\right), 7.8(\mathrm{~d}, 1 \mathrm{H}, J=8.6 \mathrm{~Hz}, \mathrm{H6})$.

7-(2-Bromoethoxy)-2-(naphthalen-1-yl)chroman-4-one (14). From the reaction of $\mathbf{1 2}(0.5 \mathrm{mmol}, 0.20 \mathrm{~g})$ and $\mathrm{NaOAc}(5.0 \mathrm{mmol}, 0.04 \mathrm{~g}), \mathbf{1 4}$ was obtained as pale yellow solid. Yield $64 \%, \mathrm{mp}: 115-117^{\circ} \mathrm{C} .{ }^{1} \mathrm{H}-\mathrm{NMR} \delta$ $2.84(\mathrm{dd}, 1 \mathrm{H}, J=16.5$ and $2.8 \mathrm{~Hz}, \mathrm{H} 3 \mathrm{a}), 3.05(\mathrm{dd}, 1 \mathrm{H}, J=16.5$ and $13.1 \mathrm{~Hz}, \mathrm{H} 3 \mathrm{~b}), 3.37(\mathrm{t}, 2 \mathrm{H}, J=6.6$, 
$\left.\mathrm{CH}_{2}-\mathrm{Br}\right), 4.21\left(\mathrm{t}, 2 \mathrm{H}, J=6.6 \mathrm{~Hz}, \mathrm{OCH}_{2}\right), 5.48(\mathrm{dd}, 1 \mathrm{H}, J=13.1$ and $2.8 \mathrm{~Hz}, \mathrm{H} 2), 6.53(\mathrm{dd}, 1 \mathrm{H}, J=2.2$ and $8.2 \mathrm{~Hz}, \mathrm{H} 5), 7.54-7.68$ (m, 3H, Ar), 7.85-8.01 (m, 4H, Ar), 7.88 (d, 1H, J = 8.6 Hz, H6).

\subsection{BACE-1 Inhibition: FRET Inhibition Assay}

Inhibition studies were performed using the following procedure: $5 \mu \mathrm{L}$ of test compound (or DMSO) were pre-incubated with $175 \mu \mathrm{L}$ of enzyme ( $10.37 \mathrm{nM}$, final concentration) in $20 \mathrm{mM} \mathrm{NaOAc}$ $\mathrm{pH} 4.5$ containing CHAPS $(0.1 \% w / v)$ for $1 \mathrm{~h}$ at r.t.; M-2420 ( $3 \mu \mathrm{M}$, final concentration) was then added and left to react for $15 \mathrm{~min}$. The fluorescence signal was read at $\lambda_{\mathrm{em}}=405 \mathrm{~nm}\left(\lambda_{\mathrm{exc}}=320 \mathrm{~nm}\right)$. DMSO concentration in the final mixture was maintained below $5 \%(v / v)$ to guarantee no significant loss of enzyme activity.Fluorescence intensities with and without inhibitor were compared and the percent inhibition due to the presence of test compounds was calculated. The background signal was measured in control wells containing all the reagents, except theenzymeand subtracted. The $\%$ inhibition due to the presence of increasing test compound concentration was calculated by the following expression: $100-\left(\mathrm{IF}_{\mathrm{i}} / \mathrm{IF}_{\mathrm{o}} \times 100\right)$ where $\mathrm{IF}_{\mathrm{i}}$ and $\mathrm{IF}_{\mathrm{o}}$ are the fluorescence intensities obtained for the enzyme in the presence and in the absence of inhibitor, respectively. Inhibition curves were obtained for each compound by plotting the \% inhibition versus the logarithm of inhibitor concentration in the assay sample. The linear regression parameters were determined and the $\mathrm{IC}_{50}$ extrapolated (GraphPad Prism 4.0, GraphPad Software Inc., San Diego, CA, USA).

\subsection{Cu(II) Chelating Assay}

The $\mathrm{Cu}$ (II) chelating activity of the compounds was determined using the bathocuproinedisulfonic acid disodium salt (BCS) assay as previously described [25]. Briefly, $50 \mu \mathrm{L}$ of a $0.25 \mathrm{mM} \mathrm{CuSO}_{4}$ solution were mixed for 2 min with $50 \mu \mathrm{L}$ of 5-20 $\mu \mathrm{M}$ compound solution in $100 \mu \mathrm{L}$ of HEPES buffer $(15 \mathrm{mM})$. Hydroxylamine $(1 \mathrm{mM})$ was added after $2 \mathrm{~min}$ in order to reduce non-chelated cupric ions into cuprous ones. Finally, $50 \mu \mathrm{L}$ of BCS ( $5 \mathrm{mM}$ ) or water (blank) was added and the absorbance at $490 \mathrm{~nm}$ was measured by spectrophotometry using a multilabel plate reader (VICTOR ${ }^{\mathrm{TM}} \mathrm{X} 3$, PerkinElmer, Waltham, MA, USA) immediately and at $5 \mathrm{~min}$. $\mathrm{Na}_{2}$ EDTA $(5-20 \mu \mathrm{M})$ was used as a positive control. The ability of the test compounds to chelate cupric ions was calculated using the following equation: chelating activity $(\%)=\left[1-\left(\mathrm{Abs}_{\mathrm{BCS}}+\right.\right.$ compound $\left.\left./ \mathrm{Abs}_{\mathrm{BCS}}\right) \times 100\right]$.

\subsection{Cell Cultures}

Human neuronal (SH-SY5Y) cells were routinely grown in Dulbecco's modified Eagle' Medium (DMEM) supplemented with $10 \%$ fetal bovine serum, $2 \mathrm{mmol} / \mathrm{L}$-glutamine, $50 \mathrm{U} \cdot \mathrm{mL}^{-1}$ penicillin and $50 \mu \mathrm{g} \cdot \mathrm{mL}^{-1}$ streptomycin at $37^{\circ} \mathrm{C}$ in a humidified incubator with $5 \% \mathrm{CO}_{2}$.

\subsection{Determination of Neurotoxicity}

To evaluate the neurotoxicity of compounds, the SH-SY5Y cells were seeded in 96-well plates at $2 \times 10^{4}$ cells/well, incubated for $24 \mathrm{~h}$ and subsequently treated with various concentrations of compounds $(1.25-40 \mu \mathrm{M})$ for $24 \mathrm{~h}$ at $37^{\circ} \mathrm{C}$ in $5 \% \mathrm{CO}_{2}$. The cell viability in terms of mitochondrial metabolic function was evaluated by the reduction in 3-(4,5-dimethyl-2-thiazolyl)-2,5-diphenyl-2H-tetrazolium bromide (MTT) to formazan as previously described [27]. The quantity of formazan was directly proportional to the number of viable cells. Briefly, the treatment medium was replaced with MTT $(5 \mathrm{mg} / \mathrm{mL})$ in phosphate-buffered saline (PBS) for $2 \mathrm{~h}$ at $37^{\circ} \mathrm{C}$ in $5 \% \mathrm{CO}_{2}$. After washing with PBS, the formazan crystals were dissolved with isopropanol. The amount of formazan was measured $(570 \mathrm{~nm}$, reference filter $690 \mathrm{~nm}$ ) using a multilabel plate reader $\left(\right.$ VICTOR $^{\mathrm{TM}}$ X3, PerkinElmer, Waltham, MA, USA). The neurotoxicity is expressed as concentration of compound resulting in $50 \%$ inhibition of cell viability. 


\subsection{Determination of Antioxidant Activity}

The total antioxidant activity of the compounds was determined using the stable DPPH radical [24]. Briefly, $150 \mu \mathrm{L}$ of $100 \mu \mathrm{M}$ DPPH in ethanol was added to $50 \mu \mathrm{L}$ of compound at different concentrations $(0.625-10 \mu \mathrm{M})$ in 96 well plate. The absorbance of the reaction mixture was measured at $490 \mathrm{~nm}$ on a multilabel plate reader (VICTOR ${ }^{\mathrm{TM}}$ X3) after $1 \mathrm{~min}, 15 \mathrm{~min}$ and $30 \mathrm{~min}$. The values was expressed as optical density of DPPH solution in absence or presence of compound.

The intracellular antioxidant activity of the compounds was evaluated in SH-SY5Y cells as previously described with minor changes [27]. Briefly, the SH-SY5Y cells were seeded in 96-well plates at $3 \times 10^{4}$ cells / well and incubated for $24 \mathrm{~h}$ at $37^{\circ} \mathrm{C}$ in $5 \% \mathrm{CO}_{2}$. Subsequently cell culture medium was removed and $100 \mu \mathrm{L}$ of $2^{\prime}-7^{\prime}$ dichlorodihydrofluorescein diacetate, $\mathrm{H}_{2}$ DCF-DA, $(10 \mu \mathrm{g} / \mathrm{mL})$ were added to each wells. After $30 \mathrm{~min}$ of incubation at room temperature the $\mathrm{H}_{2} \mathrm{DCF}-\mathrm{DA}$ solution was replaced with a solution of compound [5 and $10 \mu \mathrm{M}]$ and $\mathrm{H}_{2} \mathrm{O}_{2}(100 \mu \mathrm{M}) / \mathrm{CuSO}_{4}(25 \mu \mathrm{M})$. The ROS formation was measured (excitation at $485 \mathrm{~nm}$ and emission at $535 \mathrm{~nm}$ ) using a multilabel plate reader (VICTOR ${ }^{\mathrm{TM}} \mathrm{X} 3$ ). The values are expressed as arbitrary fluorescence units (AUF).

\subsection{Spectrophotometricdetermination of $\mathrm{Cu}(\mathrm{II})$ Chelation}

All reagents and solvents were used as received (from Aldrich, St. Louis, MO, USA) without further purification: copper(II) sulphate hydrate $(\geqslant 98 \%)$, 3-(N-Morpholino)propanesulfonic acid (MOPS, $\geqslant 99.5 \%)$, sodium hydroxide $(\geqslant 98 \%), N, N$-dimethylformamide (spectroscopic grade, DMF). A Milli-Q system (Millipore, Billerica, MA, USA) was used for the purification of water (resistivity $\geqslant 18.2 \mathrm{M} \Omega$ ). MOPS bufferstock solution were obtained by a dissolution in Milli-Q water of 3-(N-morpholino)propane sulphonic acid to a final concentration of $10^{-3} \mathrm{M}$. The $\mathrm{pH}$ was corrected with a solution of sodium hydroxide $1 \mathrm{~N}$ to a value of $\mathrm{pH}$ 7.4. Absorption spectra were recorded on a Perkin-Elmer Lambda 45 spectrophotometer at room temperature. Spectrophotometric titrations were performed as follows: stock solutions of ligands $\left(c a .10^{-3} \mathrm{M}\right)$ were prepared in DMF, diluted down to the desired concentration, in the quartz cuvette, in MOPS buffer $10^{-3} \mathrm{M} \mathrm{pH} \mathrm{7.4/DMF} \mathrm{(1:4)} \mathrm{to}$ a final volume of $2.5 \mathrm{~mL}$ and then titrated by adding increasing amounts of $\mathrm{Cu}(\mathrm{II})\left(3.04 \times 10^{-3} \mathrm{Min} \mathrm{DMF}\right)$.

Acknowledgments: This work was financially supported by a PRIN(20103W4779) Project Grant from MIUR, Italy.

Author Contributions: Federica Belluti and Angela Rampa conceived and designed the experiments; Francesca Mancini, Angela De Simone, Letizia Pruccoli, Francesco Palomba performed the experiments; Andrea Tarozzi, Nelsi Zaccheroni analyzed the data; Rita Maria Concetta Di Martino, Alessandra Bisi and Silvia Gobbi contributed reagents/materials/analysis tools; Federica Belluti and Angela Rampa wrote the paper.

Conflicts of Interest: The authors declare no conflict of interest.

\section{Abbreviations}

The following abbreviations are used in this manuscript:

$\begin{array}{ll}\text { AD } & \text { Alzheimer's disease } \\ \text { A } \beta & \text { amyloid } \beta \\ \text { APP } & \text { amyloid } \beta \text { protein precursor } \\ \text { BACE-1 } & \beta \text {-site APP cleaving enzyme-1 } \\ \text { BBB } & \text { blood brain barrier } \\ \text { chalcone } \\ \text { CNS } & \text { central nervous system } \\ \text { Fl } & \text { flavanone } \\ \text { FRET } & \text { fluorescence resonance energy transfer } \\ \text { MFCs } & \text { multifunctional compounds } \\ \text { NPs } & \text { natural products } \\ \text { NFT } & \text { neurofibrillary tangles } \\ \text { ROS } & \text { reactive oxygen species } \\ \text { SPs } & \text { senile plaques }\end{array}$




\section{References}

1. Alzheimer's Association. Alzheimer's disease facts and figures. Alzheimers Dement. 2015, 11, 332-384.

2. Geldenhuys, W.J.; Youdim, M.B.; Carroll, R.T.; Van der Schyf, C.J. The emergence of designed multiple ligands for neurodegenerative disorders. Prog. Neurobiol. 2011, 94, 347-359. [CrossRef] [PubMed]

3. Cavalli, A.; Bolognesi, M.L.; Minarini, A.; Rosini, M.; Tumiatti, V.; Recanatini, M.; Melchiorre, C. Multi-target-directed ligands to combat neurodegenerative diseases. J. Med. Chem. 2008, 51, 347-372. [CrossRef] [PubMed]

4. Naslund, J.; Haroutunian, V.; Mohs, R.; Davis, K.L.; Davies, P.; Greengard, P.; Buxbaum, J.D. Correlation between elevated levels of amyloid $\beta$-peptide in the brain and cognitive decline. JAMA 2000, 283, 1571-1577. [CrossRef] [PubMed]

5. Hardy, J. Alzheimer's disease: The amyloid cascade hypothesis: An update and reappraisal. J. Alzheimers Dis. 2006, 9, 151-153. [PubMed]

6. Yang, L.B.; Lindholm, K.; Yan, R.; Citron, M.; Xia, W.; Yang, X.L.; Beach, T.; Sue, L.; Wong, P.; Price, D.; et al. Elevated $\beta$-secretase expression and enzymatic activity detected in sporadic Alzheimer disease. Nat. Med. 2003, 9, 3-4. [CrossRef] [PubMed]

7. Silvestri, R. Boom in the development of non-peptidic $\beta$-secretase (BACE1) inhibitors for the treatment of Alzheimer's disease. Med. Res. Rev. 2009, 29, 295-338. [CrossRef] [PubMed]

8. Hong, L.; Koelsch, G.; Lin, X.; Wu, S.; Terzyan, S.; Ghosh, A.K.; Zhang, X.C.; Tang, J. Structure of the protease domain of memapsin 2 ( $\beta$-secretase) complexed with inhibitor. Science 2000, 290, 150-153. [CrossRef] [PubMed]

9. La Regina, G.; Piscitelli, F.; Silvestri, R. Synthetic strategies of nonpeptidic $\beta$-secretase (BACE1) inhibitors. J. Heter. Chem. 2009, 46, 10-17. [CrossRef]

10. Rauk, A. The chemistry of Alzheimer's disease. Chem. Soc. Rev. 2009, 38, 2698-2715. [CrossRef] [PubMed]

11. DeToma, A.S.; Choi, J.-S.; Braymer, J.J.; Lim, M.H. Myricetin: A Naturally Occurring Regulator of Metal-Induced Amyloid- $\beta$ Aggregation and Neurotoxicity. Chembiochem 2011, 12, 1198-1201. [CrossRef] [PubMed]

12. Newman, D.J.; Cragg, G.M.; Snader, K.M. Natural products as sources of new drugs over the period 1981-2002. J. Nat. Prod. 2003, 66, 1022-1037. [CrossRef] [PubMed]

13. Welsch, M.E.; Snyder, S.A.; Stockwell, B.R. Privileged scaffolds for library design and drug discovery. Curr. Opin. Chem. Biol. 2010, 14, 347-361. [CrossRef] [PubMed]

14. Williams, R.J.; Spencer, J.P. Flavonoids, cognition, and dementia: Actions, mechanisms, and potential therapeutic utility for Alzheimer disease. Free Radic. Biol. Med. 2012, 52, 35-45. [CrossRef] [PubMed]

15. Grazul, M.; Budzisz, E. Biological activity of metal ions complexes of chromones, coumarins and flavones. Coord. Chem. Rev. 2009, 253, 2588-2598. [CrossRef]

16. Belluti, F.; Piazzi, L.; Bisi, A.; Gobbi, S.; Bartolini, M.; Cavalli, A.; Valenti, P.; Rampa, A. Design, synthesis, and evaluation of benzophenone derivatives as novel acetylcholinesterase inhibitors. Eur. J. Med. Chem. 2009, 44, 1341-1348. [CrossRef] [PubMed]

17. Belluti, F.; Bartolini, M.; Bottegoni, G.; Bisi, A.; Cavalli, A.; Andrisano, V.; Rampa, A. Benzophenone-based derivatives: A novel series of potent and selective dual inhibitors of acetylcholinesterase and acetylcholinesterase-induced $\beta$-amyloid aggregation. Eur. J. Med. Chem. 2011, 46, 1682-1693. [CrossRef] [PubMed]

18. Belluti, F.; De Simone, A.; Tarozzi, A.; Bartolini, M.; Djemil, A.; Bisi, A.; Gobbi, S.; Montanari, S.; Cavalli, A.; Andrisano, V.; et al. Fluorinated benzophenone derivatives: Balanced multipotent agents for Alzheimer's disease. Eur. J. Med. Chem. 2014, 78, 157-166. [CrossRef] [PubMed]

19. Morphy, R.; Kay, C.; Rankovic, Z. From magic bullets to designed multiple ligands. Drug Discov. Today 2004, 9, 641-651. [CrossRef]

20. Belluti, F.; Rampa, A.; Piazzi, L.; Bisi, A.; Gobbi, S.; Bartolini, M.; Andrisano, V.; Cavalli, A.; Recanatini, M.; Valenti, P. Cholinesterase inhibitors: Xanthostigmine derivatives blocking the acetylcholinesterase-induced $\beta$-amyloid aggregation. J. Med. Chem. 2005, 48, 4444-4456. [CrossRef] [PubMed]

21. Mancini, F.; De Simone, A.; Andrisano, V. $\beta$-Secretase as a target for Alzheimer's disease drug discovery: An overview of in vitro methods for characterization of inhibitors. Anal. Bioanal. Chem. 2011, 400, 1979-1996. [CrossRef] [PubMed] 
22. Stachel, S.J.; Coburn, C.A.; Steele, T.G.; Jones, K.G.; Loutzenhiser, E.F.; Gregro, A.R.; Rajapakse, H.A.; Lai, M.T.; Crouthamel, M.C.; Xu, M.; et al. Structure-based design of potent and selective cell-permeable inhibitors of human $\beta$-secretase (BACE-1). J. Med. Chem. 2004, 47, 6447-6450. [CrossRef] [PubMed]

23. De Vincenzo, R.; Ferlini, C.; Distefano, M.; Gaggini, C.; Riva, A.; Bombardelli, E.; Morazzoni, P.; Valenti, P.; Belluti, F.; Ranelletti, F.O.; et al. In vitro evaluation of newly developed chalcone analogues in human cancer cells. Cancer Chemother. Pharmacol. 2000, 46, 305-312. [CrossRef] [PubMed]

24. Tarozzi, A.; Marchesi, A.; Cantelli-Forti, G.; Hrelia, P. Cold-storage affects antioxidant properties of apples in caco-2 cells. J. Nutr. 2004, 134, 1105-1109. [PubMed]

25. ̌́íha, M.; Karlíčková, J.; Filipský, T.; Macáková, K.; Hrdina, R.; Mladěnka, P. Novel method for rapid copper chelation assessment confirmed low affinity of D-penicillamine for copper in comparison with trientine and 8-hydroxyquinolines. J. Inorg. Biochem. 2013, 123, 80-87. [CrossRef] [PubMed]

26. Kim, D.O.; Lee, K.W.; Lee, H.J.; Lee, C.Y. Vitamin C equivalent antioxidant capacity (VCEAC) of phenolic phytochemicals. J. Agric. Food Chem. 2002, 50, 3713-3717. [CrossRef] [PubMed]

27. Tarozzi, A.; Bartolini, M.; Piazzi, L.; Valgimigli, L.; Amorati, R.; Bolondi, C.; Djemil, A.; Mancini, F.; Andrisano, V.; Rampa, A. From the dual function lead AP2238 to AP2469, a multi-target-directed ligand for the treatment of Alzheimer's disease. Pharmacol. Res. Perspect. 2014, 2, e00023. [CrossRef] [PubMed]

28. Kasprzak, M.M.; Erxleben, A.; Ochocki, J. Properties and applications of flavonoid metal complexes. RSC Adv. 2015, 5, 45853-45877. [CrossRef]

(C) 2016 by the authors; licensee MDPI, Basel, Switzerland. This article is an open access article distributed under the terms and conditions of the Creative Commons Attribution (CC-BY) license (http:/ / creativecommons.org/licenses/by/4.0/). 